\section{Zinc Dust Mediated Peptide Synthesis from Fmoc- Amino Acid Chlorides and Amino Acid Hydrochlorides}

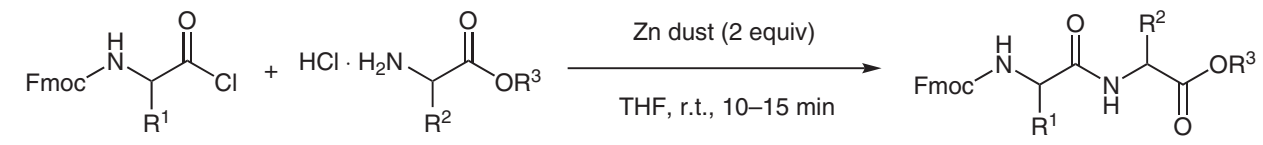

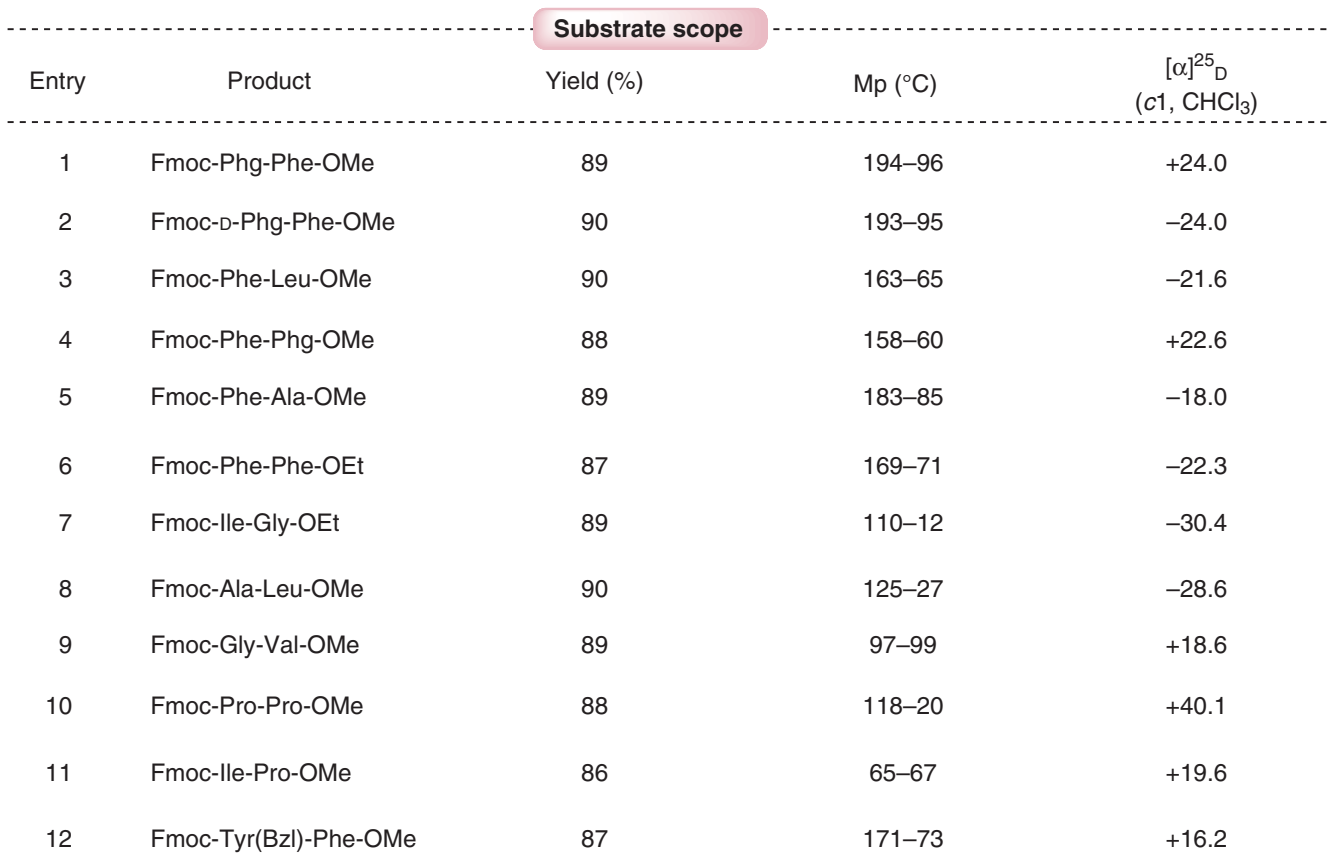

Peptide Chemistry

\section{Key words}

zinc catalysis

Fmoc-amino acid chlorides

amino acids

amidation
Significance: The construction of peptide bonds is one of the most essential and widely encountered chemical transformations in organic synthesis. In general, coupling of Fmoc-amino acid chlorides with amino acid esters requires the use of an aqueous inorganic base or an organic base. The use of these bases can cause severe issues of epimerization or cleavage of the Fmoc group. In 1998, Gopi and Suresh Babu developed a method for peptide synthesis from Fmoc-amino acid chlorides and amino acid hydrochloride salts mediated by commercially available zinc dust.
Comment: The zinc-mediated peptide coupling of Fmoc-amino acid chlorides with amino acid hydrochloride salts proceeds quickly and affords the desired peptides in high yields. This protocol is straightforward in practice, racemization free, and avoids side reactions. 